\title{
Perlindungan Hukum Investor Pasar Modal Akibat Kepailitan Perusahaan Terbuka Ditinjau dari Hukum Kepailitan dan Hukum Perusahaan Indonesia
}

\author{
Bagus Sujatmiko, * Anita Afriana**
}

\begin{abstract}
Abstrak
Berinvestasi di pasar modal dalam bentuk saham merupakan salah satu pilihan investasi. Investasi saham menjadi alternatif pembiayaan bagi perusahaan di tanah air, khususnya perusahaan terbuka di pasar modal. Seperti bentuk investasi lainnya, berinvestasi di pasar modal dalam bentuk saham selain memberikan peluang keuntungan juga memiliki risiko antara lain kepailitan, khususnya bagi para investor yang berinvestasi pada perusahaan terbuka yang mengalami pailit. Pada tulisan ini akan dilihat perlindungan hukum bagi investor pasar modal pada kepailitan perusahaan terbuka dalam sudut pandang baik hukum kepailitan dan hukum perusahaan Indonesia.
\end{abstract}

Kata Kunci: investasi saham, investor, kepailitan, pasar modal, perusahaan terbuka.

\section{Legal Protection for Capital Market Investor Due to The Bankruptcy of Listed Company Reviewed by Indonesia Bankruptcy and Company Law}

\begin{abstract}
Investing in stock in capital market is an option for most people. It gives a financing solution for most companies in the country, especially for listed companies in the capital market. Similar with other forms of investment, investing in stock in the capital market does not only come with a profit opportunity, but also risk of bankruptcy, especially for listed company investors. The purpose of this article is to identify and analyze means of legal protection for capital market investors due to the bankruptcy of listed company from the perspective of Indonesia bankruptcy and company law.
\end{abstract}

Keywords: portfolio investment, investor, bankruptcy, capital market, listed company.

\section{A. Pendahuluan}

Memasuki era globalisasi, setiap negara di seluruh belahan dunia berlomba menjadi pelopor kesejahteraan bagi masyarakatnya. Sama halnya dengan Indonesia yang

PADJADJARAN Jurnal IImu Hukum Volume 2 Nomor 2 Tahun 2015 [ISSN 2460-1543] [e-ISSN 2442-9325]

* Alumni Fakultas Hukum Universitas Padjadjaran, Jl. Dipati Ukur No 35, Bandung, sujatmiko@gmail.com, S.H. (Universitas Padjadjaran)

** Dosen Fakultas Hukum Universitas Padjadjaran, Jl. Dipati Ukur No 35, Bandung, nie782003@yahoo.com, S.H., M.H. (Universitas Padjadjaran) 
pembangunan di bidang ekonominya diarahkan berdasarkan Pancasila dan Undang-Undang Dasar 1945 (UUD 1945) bertujuan untuk meningkatkan kesejahteraan dan kemakmuran rakyat secara adil dan merata, serta mengembangkan kehidupan masyarakat dan penyelenggaraan negara yang maju dan demokratis. ${ }^{1}$ Pasar modal sebagai salah satu sarana pembangunan nasional saat ini telah berkembang pesat dan keberadaannya menjadi salah satu alternatif pembiayaan dalam pembangunan nasional. ${ }^{2}$ Mengingat besarnya kebutuhan dana dalam negeri untuk mempertahankan laju pertumbuhan ekonomi, keberadaan pasar modal diharapkan dapat menghimpun dana yang bersumber baik dari luar maupun dalam negeri yang bersumber dari masyarakat Indonesia.

Saat ini pasar modal menjadi indikator kemajuan perekonomian suatu negara serta penunjang perkembangan ekonomi negara. ${ }^{3}$ Pasar modal menyediakan sarana diversifikasi risiko, baik untuk pihak yang membutuhkan dana (emiten) maupun pemodal. Fungsi lainnya adalah dalam mekanisme alokasi modal dan pemantauan korporasi, serta sarana bagi pemerintah untuk melaksanakan ekonomi pasar disamping memanfaatkan baik kebijaksanaan fiskal maupun moneter. ${ }^{4}$ Tentu saja keberadaannya menjadi salah satu instrumen penting bagi negara baik untuk menggerakkan perekonomian maupun sebagai langkah pemulihan terhadap krisis ekonomi.

Krisis ekonomi yang melanda Indonesia pada tahun 1997 telah meruntuhkan fondasi perekonomian nasional. Mengatasi krisis tersebut, salah satu upaya pemerintah adalah meningkatkan jumlah investasi di Indonesia. ${ }^{5}$ Investasi ini diprioritaskan pada jenis investasi berdasarkan ekuitas (equity based investment) seperti penanaman modal asing dalam bentuk foreign direct investment (investasi langsung) dan investasi melalui pasar modal dalam bentuk portofolio investment (investasi portofolio). ${ }^{6}$

Likuidasi terhadap 64 bank akibat krisis ekonomi pada tahun 1997 menjadi bukti nyata kerugian besar investor pasar modal. Sebanyak 11 dari 64 bank yang dilikuidasi adalah bank dalam bentuk perusahaan terbuka atau emiten di pasar

1 Dapat dilihat dalam Penjelasan Umum Undang-Undang Nomor 8 Tahun 1995 Tentang Pasar Modal (UUPM).

2 Jusuf Anwar, Pasar Modal Sebagai Sarana Pembiayaan dan Investasi, Seri Pasar Modal 1, Bandung: Alumni, 2005, hlm. 2.

3 Gunawan Widjaja dan Wulandari Risnamanitis D., Seri Pengetahuan Pasar Modal: Go Public dan Go Private di Indonesia, Cetakan Kesatu, Jakarta: Kencana, 2009, hlm. 1.

4 Robert Pardy, "Institutional Reform in Emerging Securities Marketts", The World Bank, Washington DC-USA, 1992, hlm. 2 dalam Jusuf Anwar, Op. cit, hlm. 4.

5 Dapat dilihat dalam Peraturan Presiden Nomor 7 Tahun 2005 tentang Rencana Pembangunan Jangka Menengah Nasional, hIm. 479.

6 Lastuti Abubakar, Transaksi Derivatif di Indonesia: Tinjauan Hukum tentang Perdagangan Derivatif di Bursa Efek, Bandung: Books Terace \& Library, 2009, hlm. 4. 
modal. Kepailitan perusahaan terbuka tersebut membuat investor pasar modal yang memegang saham menjadi kehilangan dana dalam jumlah besar dan hampir tidak dapat melakukan upaya penyelamatan dana investasi mereka. Beberapa pakar seperti Jamin Ginting memberi pandangan bahwa harus ada tindakan hukum yang dapat melindungi investor pasar modal akibat hukum kepailitan, salah satunya dengan menempatkanya sebagai kreditor apabila emiten atau perusahaan terbuka tempat ia berinvestasi dinyatakan pailit. ${ }^{7}$ Banyaknya kasus kepailitan terhadap perusahaan pada umumnya, dan khususnya perusahaan terbuka, membuat isu ini tetap menarik untuk dikaji lebih lanjut. Hal ini bukan merupakan hal yang baru terjadi, namun perlindungan hukum bagi investor ketika perusahaan terbuka dinyatakan pailit belum diatur secara eksplisit dalam bentuk aturan.

\section{B. Investasi Saham di Pasar Modal}

Emiten atau yang juga dikenal sebagai perusahaan terbuka berdasarkan Pasal 1 angka 6 Undang-Undang Nomor 8 Tahun 1995 tentang Pasar Modal (UUPM) diartikan sebagai pihak yang melakukan penawaran umum. Istilah penawaran umum ini sering dikaitkan dengan istilah go public. Menurut Sumantoro, pada hakikatnya go public secara terjemahan adalah proses perusahaan yang 'go public' atau 'pergi ke masyarakat', artinya perusahaan itu memasyarakatkan dirinya dengan jalan memberikan sarana untuk masyarakat masuk dalam perusahaannya dengan menerima penyertaan masyarakat dalam usahanya, baik dalam pemilikan maupun dalam penetapan kebijaksanaan pengelolaan perusahaannya. ${ }^{8}$

Ketentuan yang berlaku memberikan beberapa persyaratan untuk dapat menjadi perusahaan publik atau perusahaan terbuka. Persyaratan tersebut diantaranya: setiap perseroan terbatas yang telah beroperasi sekurang-kurangnya 12 bulan; memiliki aktiva bersih berwujud sekurang-kurangnya Rp5.000.000.000,00 dengan laporan keuangan auditan tahun buku terakhir memperoleh opini wajar tanpa pengecualian dari akuntan publik yang terdaftar di Badan Pengawas Pasar Modal dan Lembaga Keuangan (Bapepam); menjual sekurang-kurangnya 50.000 .000 saham atau 35\% dari jumlah saham yang diterbitkan yang lebih kecil; dan jumlah pemegang saham publik sekurang-kurangnya 500 pihak. Dengan terpenuhinya persyaratan tersebut, suatu perusahaan dapat menjadi perusahaan publik yang sahamnya diperdagangkan di bursa. ${ }^{9}$

7 Jamin Ginting, "Kedudukan Pemegang Saham (Investor) dalam Kepailitan Perusahaan Go Public", Law Review Fakultas Hukum Universitas Pelita Harapan Jakarta, Volume IV No. 3, Maret 2005, hlm. 2.

8 Sumantoro, Aspek Hukum Pasar Modal dalam Hukum dan Pembangunan No. 1, Jakarta: Fakultas Hukum Universitas Indonesia, 1978, hlm. 64.

9 Bursa Efek Indonesia, "Panduan Go Public", http://www.idx.co.id/portals/khusus PDF/go\%20public \%20new2.pdf., hlm. 5. 
Perusahaan yang memutuskan untuk menjual sahamnya ke masyarakat secara go public akan mendapatkan manfaat tertentu. Manfaat utamanya adalah memperoleh pembiyaan atau dana tambahan untuk menjalankan perusahaannya. Namun, disamping manfaat atau keuntungan tersebut, terdapat pula beberapa konsekuensi yang harus ditanggung oleh perusahaan.

Saham adalah surat berharga atas bukti penyertaan atau pemilikan individu maupun institusi dalam suatu perusahaan. ${ }^{10}$ Wujud saham adalah selembar kertas yang menerangkan kepemilikan kertas tersebut adalah pemilik perusahaan yang menerbitkan kertas. Dengan memiliki saham, investor mempunyai hak terhadap pendapatan dan kekayaan perusahaan setelah dikurangi dengan semua kewajiban perusahaan.

Menurut Widioatmodjo, terdapat keuntungan dan kerugian dalam investasi saham, yaitu: ${ }^{11}$

1. Keuntungan

a. Dividen, yaitu bagian keuntungan perusahaan yang akan dibagikan kepada pemegang saham;

b. Capital gain, yaitu keuntungan dari hasil jual/beli saham, berupa selisih antara nilai jual yang lebih tinggi daripada nilai beli saham;

c. Saham perusahaan, seperti tanah atau aktiva berharga sejenis, nilainya akan meningkat sejalan dengan waktu dan sejalan dengan perkembangan atau kinerja perusahaan; dan

d. Saham dapat dijaminkan ke bank sebagai agunan untuk memperoleh kredit.

2. Kerugian

a. Capital loss, yaitu kerugian dari hasil jual/beli saham berupa selisih antara nilai jual yang lebih rendah daripada nilai beli saham; dan

b. Opportunity loss, kerugian berupa selisih suku bunga deposito dikurangi total hasil yang diperoleh dari investasi, seandainya terjadi penurunan harga dan tidak dibaginya deviden.

Kerugian karena perusahaan dilikuidasi adalah ketika nilai likuidasi yang dibagikan lebih rendah dari harga beli saham. Setelah masuk pasar sekunder, perdagangan saham akan menjadi dinamis. Perkembangan teknologi yang merambah sektor pasar modal memungkinkan investor dan emiten untuk melakukan transaksi jual-beli saham dalam waktu singkat dimana saja. Harga saham yang telah diperdagangkan di pasar sekunder ini dapat berubah setiap saat. Perubahan tersebut dipengaruhi oleh faktor internal maupun eksternal, yakni

\footnotetext{
10 Pandji Anoraga, Pengantar Pasar Modal, Jakarta: Rineka Cipta, 2010, hlm. 57.

11 Sawidji Widoatmodjo, Cara Cepat Memulai Investasi Saham Panduan Bagi Pemula, Jakarta: Elex Media Komputindo, 2004, hlm. 42.
} 
sebagai berikut: ${ }^{12}$

1. Faktor internal

a. Laba penjualan;

b. Nilai kekayaan total;

c. Likuiditas;

d. Penjualan; dan

e. Pertumbuhan aktiva tahunan.

2. Faktor eksternal

a. Tingkat suku bunga;

b. Fluktuasi nilai tukar mata uang; dan

c. Kondisi ekonomi, sosial, politik, dan keamanan suatu negara.

Nilai likuiditas diartikan sebagai keadaaan dimana harta kekayaan perusahaan atau aset dapat diperjualbelikan dengan cepat atau tidak ada suatu masalah pada aset untuk dialihkan. Likuiditas ini juga dipengaruhi oleh adanya tuntutan hukum terhadap perusahaan atau asetnya baik secara gugatan keperdataan ataupun adanya suatu putusan kepailitan.

\section{Dampak Kepailitan Perusahaan Terbuka}

Pada ketentuan Pasal 2 ayat (1) Undang-Undang Nomor 37 Tahun 2004 tentang Kepailitan dan Penundaan Kewajiban Pembayaran Utang (UU KPKPU) disebutkan bahwa syarat kepailitan adalah debitor yang mempunyai dua atau lebih kreditor dan tidak membayar lunas sedikitnya satu utang yang telah jatuh tempo dan dapat ditagih. Debitor kemudian dinyatakan pailit dengan putusan pengadilan, baik atas permohonannya sendiri maupun permohonan satu atau lebih kreditornya.

Sifat transaksi pasar modal yang sangat dinamis membuat sebuah perusahaan terbuka sangat rentan mendapati kepailitan. Sifat yang dinamis ini juga membuat perdagangan saham di Bursa Efek Indonesia (BEI) memiliki nilai yang sangat fluktuatif atau terus naik turun mengikuti sentimen pasar. Pada umumnya sifat ini banyak dimanfaatkan para investor untuk mendapatkan keuntungan dari membeli saham di pasar modal. Nilai harga saham yang terus berubah ini dipengaruhi oleh banyak faktor, baik internal maupun eksternal dan perusahaan pemilik saham yang di-listing di bursa atau emiten. Besar kecilnya kurva penawaran dan permintaan terhadap produk dari perusahaan emiten adalah faktor dominan terhadap penilaian harga saham.

Dampak putusan pailit bagi sebuah perusahaan berdasarkan Pasal 24 UU KPKPU adalah seluruh organ perusahaan akan kehilangan kendali atas harta kekayaan perusahaannya. Apabila hal tersebut terjadi pada perusahaan terbuka,

\footnotetext{
12 Ibid, hlm. 45.
} 
maka berpotensi pada berhentinya proses produksi. Dengan demikian, putusan pailit akan berimbas pula pada kurva penawaran dan permintaan terhadap produk perusahaan tersebut yang membuat harga saham di pasar modal menjadi turun drastis.

Peristiwa kepailitan yang berdampak pada turunnya harga saham dapat memicu terjadinya proses delisting atau penghapusan saham emiten yang tercatat di bursa. Untuk menjaga terlaksananya perdagangan efek yang teratur serta wajar dan efisien, bursa dapat melakukan penghentian sementara pelaksanaan perdagangan bursa. Sesuai dengan Pasal V Peraturan PT Bursa Efek Jakarta Nomor IIA tentang Perdagangan Efek Bersifat Ekuitas (Peraturan BEI No. II-A), salah satu penyebab penghentian sementara perdagangan bursa adalah adanya indikasi permasalahan hukum terkait force majeure. Pada Pasal III.3 Peraturan PT Bursa Efek Jakarta Nomor I-I tentang Penghapus Pencatatan dan Pencatatan Kembali Saham di Bursa (Peraturan BEI No. I-I) dinyatakan bahwa apabila terjadi suatu kondisi yang mengharuskan bursa melakukan penghapusan terhadap saham terkait adanya permasalahan hukum terhadap emiten, bursa dapat melakukan suspensi selama 5 hari terhadap saham emiten untuk selanjutnya diperjualbelikan hanya di pasar negosiasi saja.

Keadaan suspensi menyebabkan saham sebuah emiten dihentikan sementara penjualannya di bursa. Hal ini menurut Gilman Pradana dilakukan agar investor yang berkeinginan memiliki saham di pasar modal tidak dirugikan apabila membeli saham yang sedang 'sakit' atau keadaan finansialnya tidak menguntungkan untuk berinvestasi. Kejadian seperti kepailitan dapat menyebabkan sebuah perusahan mati total sehingga investor dapat kehilangan dananya, dan untuk berjaga-jaga walaupun baru hanya permohonan kepailitan saham emiten tersebut akan disuspensi. ${ }^{13}$

Di lain pihak, keadaan suspensi menciptakan potensi kerugian yang besar bagi investor pasar modal. Keadaan ini disebut sebagai lock-up atau saham terkunci di bursa. Pada keadaan seperti ini investor menjadi tidak dapat memperjualbelikan sahamnya atau kehilangan kesempatan untuk mendapat capital gain. Apabila keadaan saham atau keadaan perusahaan tersebut tidak kunjung menjadi lebih baik atau permasalahan hukum terus berlanjut, maka setelah proses suspensi ada kemungkinan saham milik perusahaan efek akan masuk pasar negosiasi hingga akhirnya di-delisting.

Capital gain yang diperoleh investor dari hasil selisih harga jual dan beli menjadi sulit untuk dilakukan karena ketika disuspensi saham yang tercatat di papan akan dihentikan perdagangannya oleh bursa. Namun melihat kembali Pasal V.1.

13 Hasil wawacara Ketua BEI Cabang Bandung, Gilman Pradana, pada 5 Februari 2015. 
Peraturan BEI No. II-A, transaksi bursa yang sudah terjadi sebelum dihentikannya perdagangan dianggap tetap berlaku, sehingga masih dimungkinkan diperoleh capital gain apabila sehari sebelum disuspensi investor masih sempat melakukan transaksi di pasar reguler yang artinya ketika transaksi selesai pada $T+3$ investor masih mendapat keuntungan dari hasil penjualan sahamnya di bursa.

Kesempatan lain investor untuk memperoleh keuntungan lewat deviden perusahaan masih mungkin saja terjadi. Namun, adakalanya berdasarkan Pasal 70 Undang-Undang Nomor 40 Tahun 2007 tentang Perseroan Terbatas (UU PT) kemungkinan investor untuk mendapat laba semakin kecil mengingat kondisi perusahaan yang sedang pailit karena berdasarkan ketentuan tersebut laba hanya akan dibagikan apabila mempunyai saldo laba positif. Hal ini menunjukkan peristiwa kepailitan hampir sama sekali tidak memberikan celah untuk investor untuk mencegah kerugian yang akan dialaminya sehingga dianjurkan perlu kejelian dan pengetahuan khusus di bidang pasar modal apabila ingin memiliki saham perusahaan dan keterbukaan informasi yang jelas dari emiten.

\section{Perlindungan Hukum Investor Pasar Atas Kepailitan Perusahaan Terbuka}

1. Perlindungan Hukum Investor Berdasarkan Mekanisme Perdagangan di Pasar Modal

\section{a. Proses Keterbukaan Informasi sebagai Bentuk Perlindungan Investor}

Prinsip keterbukaan adalah pedoman umum yang mensyaratkan emiten atau perusahaan terbuka dan pihak lain yang tunduk pada UUPM untuk menginformasikan kepada masyarakat dalam waktu yang tepat seluruh informasi material mengenai usaha atau efeknya yang dapat berpengaruh terhadap keputusan pemodal dalam melakukan investasi di pasar modal sebagaimana dijelaskan dalam Pasal 1 angka 25 UUPM. Pada Pasal 86 ayat (1) UUPM diatur bahwa seluruh perusahaan terbuka atau emiten yang telah terdaftar menjadi anggota bursa wajib membuka informasinya melalui laporan berkala dalam rangka memenuhi prinsip keterbukaan di pasar modal dan berdasarkan Pasal 89 UUPM, informasi tersebut diberikan agar tersedia untuk masyarakat umum sebagai investor pasar modal.

Prinsip keterbukaan adalah bentuk riil dari usaha pencegahan kerugian investor pasar modal yang dilakukan oleh pihak otoritas pada setiap transaksi di pasar modal. Hal ini dimaksudkan agar investor yang memilih berinvestasi di pasar modal tidak tertipu atau dapat mengambil keputusan yang benar. Berdasarkan buku Ikhtisar Ketentuan Pasar Modal yang dikeluarkan oleh Bapepam-LK, ${ }^{14}$ ada 4 jenis utama dari bentuk penerapan prinsip keterbukaan, yakni:

\footnotetext{
14 Tim Penyusun, Ikhtisar Ketentuan Pasar Modal, Jakarta: National Legal Reform Program-Badan Pengawas Pasar Modal dan Lembaga Keuanagan, 2010, hlm. 1038-1042.
} 
1) Keterbukaan informasi yang harus segera diumumkan ke publik;

2) Keterbukaan informasi bagi pemegang saham tertentu;

3) Keterbukaan informasi bagi emiten atau perusahaan publik yang dimohonkan pernyataan pailit;

4) Keterbukaan informasi mengenai biaya penawaran umum.

Melihat kembali kemungkinan akibat hukum dari adanya putusan kepailitan pada perusahaan terbuka yakni suspensi saham hingga delisting atau sederhanya terjadi lock up, maka investor sebagai konsumen pasar modal sangat membutuhkan informasi yang benar terkait keadaan emiten tempat ia menanamkan modalnya. Keterbukaan informasi ini dapat memberikan kesempatan bagi investor untuk meminimalisasi kerugian yang akan diderita akibat kepailitan perusahaan terbuka atau bahkan mencegah terjadinya kerugian investor. Adapun hal-hal yang penting bagi emiten guna kepentingan investor atas adanya putusan atau permohonan kepailitan kepada emiten berdasarkan Peraturan Bapepam-LK Nomor X.K.5 tentang Keterbukaan Informasi Bagi Emiten atau Perusahaan Publik yang Dimohonkan Pernyataan Pailit (Peraturan Bapepam-LK No. X.K.5) adalah penyampaian berita tertulis kepada Bapepam dan bursa efek secepat mungkin paling lambat hari kerja kedua sejak emiten atau perusahaan publik mengalami kegagalan atau mengetahui ketidakmampuan menghindari kegagalan pembayaran utang.

Kemudian dalam rangka preventif, investor juga dapat memanfaatkan informasi yang dibuka oleh emiten secara berkala sesuai dengan Peraturan Bapepam-LK Nomor X.K.1 tentang Keterbukaan Informasi yang Harus Segara Diumumkan Kepada Publik (Peraturan Bapepam-LK No. X.K.1). Pada peraturan tersebut emiten diwajibkan untuk membuka informasi terkait usahanya, baik aksi perusahaan berupa penggabungan atau peleburan perusahaan atau kegiatan produksi perusahaan yang akan mempengaruhi nilai saham di bursa. Pada angka 2 Peraturan Bapepam-LK No. X.K.1 diatur tentang kontrak atau perikatan yang dilakukan oleh emiten ditambah dengan kewajibannya untuk menyampaikan laporan tahunan yang juga memuat laporan keuangan yang diamanatkan dalam Peraturan Bapepam-LK Nomor X.K.6 tentang Kewajiban Penyampaian Laporan Tahunan Bagi Emiten atau Perusahaan Publik (Peraturan Bapepam-LK No. X.K.6).

Informasi-informasi yang disediakan oleh bursa kepada publik ini dapat dijadikan bahan pertimbangan bagi investor untuk menentukan langkah investasi yang dapat diambil guna menghindari kerugian yang dapat terjadi akibat adanya permohonan pernyataan pailit kepada emiten. Salah satu langkah yang dapat diambil oleh investor ketika melihat potensi kerugian adalah metode cutting loose. Metode ini pada dasarnya menganjurkan investor untuk menjual sahamnya ketika sentimen pasar terhadap saham emiten mulai rendah. Investor harus menjual sahamnya walaupun harga jual sama atau bahkan lebih rendah dari harga beli 
dengan anggapan lebih baik daripada menahan saham. Pelanggaran terhadap prinsip keterbukaan dapat merugikan semua pihak dalam pasar modal khususnya investor. Adapun sanksi yang mungkin diberikan kepada emiten yang melakukan pelanggaran adalah sanksi administratif sesuai Pasal 102 UUPM hingga sanksi pidana yang diatur dalam Bab XV UUPM.

\section{b. Akibat Suspensi dan Proses Delisting Saham Emiten}

Adakalanya informasi yang dibuka oleh bursa kepada investor tidak dapat dimanfaatkan dengan baik oleh investor sehingga ada beberapa pakar yang beranggapan bahwa kerugian investor akibat kepailitan adalah murni risiko bisnis. Hal ini terjadi karena memang tidak semua investor memiliki pengetahuan yang cukup untuk melakukan perhitungan yang tepat atas potensi kerugian akibat kepailitan terhadap emiten atau perusahaan terbuka. Suspensi dan penghapusan saham yang dicatat di bursa (delisting) menimbulkan kerugian pada investor karena terjadi lock up terhadap saham di bursa, padahal keadaan ini dapat diatasi dengan mekanisme perdangangan yang telah ada di pasar modal.

Perdagangan saham di pasar modal saat ini semakin berkembang seiring dengan perkembangan teknologi. Penjualan saham saat ini telah dilaksanakan melalui scriptless trading atau perdagangan tanpa warkat. Berdasarkan Peraturan BEI No. II-A, BEI membagi pasar saham ke dalam 3 (tiga) segmen jenis pasar saham di pasar modal, yakni: pasar regular, pasar tunai, dan pasar negosiasi.

Berdasarkan hasil penelitian, hampir seluruh kasus delisting emiten disebabkan karena adanya permohonan pernyataan kepailitan adalah melalui forced delisting. Pada umumnya, voluntary delisting dilakukan oleh emiten yang berniat go private atau merubah status perusahaan dari terbuka menjadi tertutup sesuai dengan pertimbangan dari organ perusahaan terkait strategi bisnis. Beberapa permasalahan yang ditemukan pada delisting emiten adalah akibat kepailitan melaluiforced delisting.

Berdasarkan ketentuan Pasal III.3 Peraturan BEI No. I-I, prosedur delisting dilakukan terlebih dahulu dengan dilakukannya suspensi terhadap saham emiten. Kemudian setelah dilakukan suspensi, apabila masih dimungkinkan perdagangan saham maka saham emiten dapat diperjualbelikan hanya di pasar negosiasi selama paling lama 24 bulan ( 2 tahun). Kesempatan investor untuk memperkecil kerugian dapat dilakukan pada saat proses perdagangan saham dipindahkan ke pasar negosiasi. Pada tahap ini, investor dapat secara langsung melakukan proses tawarmenawar dengan calon pembelinya. Oleh sebab itu, masuknya saham ke pasar negosiasi sebenarnya adalah upaya bursa untuk menyelamatkan investor apabila nantinya emiten tersebut resmi dihapus dari saham dan diputus pailit oleh pengadilan. 


\section{c. Ketentuan Pembelian Kembali (Buy Back) Saham Emiten Akibat Delisting}

Delisting saham emiten di bursa adalah kejadian yang paling dihindari oleh seluruh investor, sebab hal inilah yang disinyalir sebagai keadaan paling buruk dari kegiatan investasi di pasar modal. Keadaan ini membuat investor manapun baik yang dananya banyak maupun sedikit hampir tidak dapat melakukan apapun untuk menyelamatkan dana mereka. Lock up saham menjadikan investor hanya dapat menunggu kebijakan yang mungkin diambil oleh otoritas baik oleh bursa efek, Otoritas Jasa Keuangan (OJK), ataupun emiten itu sendiri untuk menanggulangi kerugian yang dialami oleh investor.

Sebagaimana telah dijelaskan di atas, apabila terjadi delisting maka ada perlakukan tertentu yang dilakukan oleh pihak bursa kepada emiten yang sedang dalam masalah. Berdasarkan ketentuan dalam Peraturan BEI No. I-I, perlakuan tersebut dilihat dari tata cara penghapusannya. Dilihat dari pengapusan saham bursa berdasarkan Peraturan BEI tersebut, terdapat dua cara yakni melalui voluntary delisting atau melalui forced delisting. Apabila delisting dilakukan atas inisiatif emiten maka terhadapnya akan dikenakan kewajiban melakukan pembelian kembali sahamnya yang telah dilempar di bursa. Pada umumnya delisting dengan cara ini dilakukan sebagai bentuk strategi bisnis, namun tidak menutup kemungkinan pula dikarenakan adanya permohonan pernyataan pailit kepada emiten.

Penghapusan paksa oleh bursa atau forced delisting adalah pengapusan yang dilakukan karena alasan adanya peristiwa signifikan yang berpengaruh negatif terhadap kelangsungan usaha emiten baik secara finansial atau hukum dan dikarenakan suspensi saham di pasar reguler dan tunai terhadap emiten yang telah berlangsung sekurang-kurangnya 24 bulan terakhir. Kewajiban emiten untuk melakukan buy back saham tidak dijelaskan pada forced delisting, sehingga nasib investor yang memiliki saham pada emiten yang dinyatakan pailit dirugikan. Hasil wawancara kepada Ketua Umum Masyarakat Investor Sekuritas Indonesia (MISSI), Bapak Sanusi menyatakan, ketiadaan peraturan buy back saham saat perusahaan di-delisting sangat merugikan investor sehingga seharusnya kejadian tersebut menjadi tanggung jawab dari BEI ataupun OJK. ${ }^{15}$

\section{Perlindungan Hukum Investor Pasar Modal Melalui Gugatan Keperdataan}

a. Gugatan Keperdataan Berdasarkan Undang-Undang Nomor $\mathbf{4 0}$ Tahun 2007 Tentang Perseroan Terbatas

Perseroan terbatas adalah bentuk persekutuan yang diakui sebagai badan hukum di Indonesia. Pengakuan sebagai badan hukum ini diberikan berdasarkan UUPT yang dinyatakan bahwa perseroan terbatas adalah badan usaha yang berbentuk badan 15 Hasil wawancara dengan Ketua Umum Masyarakat Investor Sekuritas Indonesia (MISSI), Bpk. Sanusi, pada 12
Desember 2014. 
hukum. Segala kegiatan terkait perseroan diatur oleh hukum sehingga hak dan kewajiban pelaku usaha menjadi lebih aman karena adanya jaminan kepastian hukum dari undang-undang.

Perbuatan hukum adalah perbuatan yang akibatnya diatur oleh hukum. Maksud dari akibatnya diatur oleh hukum adalah konsekuensi dari suatu perbuatan telah diatur dalam peraturan perundang-undangan. Sebagai contoh dari konsekuensi yang diatur dalam peraturan perundang-undangan adalah akibat perbuatan melanggar hukum dalam Pasal 1365 Kitab Undang-Undang Hukum Perdata (KUHPerdata): "Tiap perbuatan yang melanggar hukum dan membawa kerugian kepada orang lain, mewajibkan orang yang menimbulkan kerugian itu karena kesalahannya untuk mengganti kerugian tersebut."

Pasal ini memberikan definisi tentang perbuatan hukum yang pada intinya adalah sebuah perbuatan yang melanggar ketentuan dalam peraturan perudangundangan. Pasal ini juga menjadi dasar bagi segala perbuatan yang diatur dalam peraturan perundang-undangan apabila merugikan orang lain, maka harus ada kompensasi atau melakukan suatu kewajiban yang dapat menutupi kerugian tersebut. Pada umumnya kompensasi yang wajib dilakukan oleh seorang pelanggar atau orang yang melakukan perbuatan melawan hukum juga telah diatur dalam pasar yang dilanggar. UUPT juga mengatur hal serupa yakni adanya konsekuensi dari sebuah tindakan yang dianggap melanggar hukum atau merugikan orang lain. Pemegang saham sebagai pendiri perseroan melalui UUPT diberikan hak-hak tertentu seperti yang terdapat dalam Pasal 52 ayat (1) UUPT yang memberikan hak dasar kepada pemegang saham untuk:

a. menghadiri dan mengeluarkan suara dalam RUPS;

b. menerima pembayaran dividen dan sisa kekayaan hasil likuidasi; dan

c. menjalankan hak lainnya berdasarkan undang-undang ini.

Pada pasal tersebut, pemegang saham diberikan hak untuk mendapatkan sejumlah uang hasil usaha perseroan yang disebut deviden. Deviden berdasarkan Pasal 71 UUPT adalah seluruh laba bersih yang dikurangi penyisihan untuk cadangan dana usaha perseroan yang akan dibagikan sesuai dengan jumlah saham yang dimiliki kepada pemegang saham sebagai pemilik perusahaan. Berdasarkan Pasal 1 angka 4 UUPM, saham termasuk efek yang diperjualbelikan di bursa. Saham yang diperjualbelikan di bursa adalah saham emiten atau yang berdasarkan Pasal 1 angka 6 UUPM, emiten adalah pihak yang melakukan penawaran umum.

Selanjutnya pengertian penawaran umum ini sendiri berdasarkan Pasal 1 angka 15 UUPM adalah kegiatan penawaran efek (saham) yang dilakukan oleh emiten untuk menjual efek kepada masyarakat. Sehingga jelas pembeli atau investor saham di pasar modal akan menjadi pemegang saham pada sebuah perseroan terbatas yang telah melakukan penawaran umum yang selanjutnya disebut emtiten atau 
perusahaan terbuka. Investor sebagai pemegang saham di perusahaan terbuka dijamin pula oleh Pasal 52 ayat (1) UUPT untuk mendapat hak atas dividen dan hakhak lain yang diatur dalam UUPT. Apabila pemegang saham tidak mendapatkan haknya, maka berdasarkan Pasal 61 UUPT:

Setiap pemegang saham berhak mengajukan gugatan terhadap perseroan ke pengadilan negeri apabila dirugikan karena tindakan perseroan yang dianggap tidak adil dan tanpa alasan wajar sebagai akibat keputusan RUPS, Direksi, dan/atau dewan komisaris.

Dikaitkan dengan terjadinya peristiwa kepailitan terhadap sebuah perusahaan terbuka, hak dari investor sebagai pemegang saham akan dilanggar karena tidak memperoleh hak deviden. Hal ini mengacu pada Pasal 71 ayat (3) UUPT yang disyaratkan adanya kondisi laba positif agar dividen dapat dibagikan kepada pemegang saham. Dengan demikian, adanya proses kepailitan tentunya akan menghambat pembagian dividen kepada para pemegang saham.

Pasal 61 UUPT menjadi pegangan para investor apabila merasa haknya dilanggar oleh pihak perusahaan terbuka dengan terjadinya kepailitan. Selain pasal tersebut, ada juga Pasal 97 ayat (6) UUPT yang diatur mengenai pemberikan hak kepada pemegang saham untuk menggugat anggota direksi apabila adanya kesalahan anggota direksi dalam menjalankan perusahaan. Seorang direksi menjalankan kepengurusan yang dipercayakan kepadanya, sehingga harus melaksanakannya dengan itikad baik dan penuh tanggung jawab. Jika direksi terbukti salah/lalai dalam menjalankan kepengurusannya dan mengakibatkan perseroan rugi sampai mengakibatkan pailitnya perseroan, pemegang saham perseroan sesuai dengan ketentuan yang ada berhak menggugat direksi bersangkutan untuk diminta pertanggungjawaban secara penuh sampai dengan harta pribadinya.

Selain pasal-pasal yang telah disebutkan di atas ada pula pasal yang memberikan hak kepada investor sebagai pemegang saham untuk menuntut buy back atas saham yang dimilikinya yakni dalam Pasal 62 UUPT yang berbunyi:

Setiap pemegang saham berhak meminta kepada perseroan agar sahamnya dibeli dengan harga wajar apabila yang bersangkutan tidak menyetujui tindakan perseroan yang merugikan pemegang saham atau perseroan, berupa:

a. perubahan anggaran dasar;

b. pengalihan atau penjaminan kekayaan perseroan yang mempunyai nilai lebih dari 50\% kekayaan bersih perseroan; atau

c. penggabungan, peleburan, pengambilalihan, atau pemisahan.

Berdasarkan pasal ini, investor sebagai pemegang saham dapat menuntut adanya kewajiban buy back saham atas saham yang mereka miliki dari proses 
pembelian di pasar modal. Adapun untuk melakukan pembelian kembali, perusahaan harus melihat ketentuan yang diatur dalam Pasal 37 UUPT yang pada intinya pembelian kembali tidak boleh menyebabkan harta kekayaan bersih perusahaan menjadi lebih kecil dari jumlah modal yang ditempatkan ditambah cadangan wajib yang telah disisihkan.

\section{b. Gugatan Keperdataan Berdasarkan Ketentuan di Bidang Pasar Modal}

Pasar modal di negara manapun tidak lepas dari kecurangan, baik penipuan atau manipulasi. Trik dalam melakukan perdagangan memang banyak sekali ragam dan caranya. Celakanya adakalanya trik-trik tersebut tidak terakomodasi oleh otoritas sehingga dapat merugikan investor sebagai konsumen di pasar modal. Tindakan kecurangan di pasar modal pada umumnya dibagi menjadi bentuk manipulasi pasar dan penipuan. Manipulasi pasar dapat mengakibatkan perubahan harga saham yang dianggap semu atau tidak wajar, sedangkan penipuan mengakibatkan informasi atau keadaan yang sebenarnya tidak tersampaikan kepada investor.

Apabila terjadi kepailitan pada emiten dan ada investor yang merasa dirugikan karena hal tersebut, investor yang dalam Undang-Undang Nomor 21 Tahun 2011 Tentang Otoritas Jasa Keuangan (UU OJK) diakui sebagai seorang konsumen pasar modal, dapat melaporkan kerugiannya kepada OJK untuk diupayakan. Berdasarkan Pasal 29 UU OJK dinyatakan bahwa:

OJK melakukan pelayanan pengaduan konsumen yang meliputi:

a. Menyiapkan perangkat yang memadai untuk pelayanan pengaduan konsumen yang dirugikan oleh pelaku di lembaga jasa keuangan;

b. Membuat mekanisme pengaduan konsumen yang dirugikan oleh pelaku di lembaga jasa keuangan; dan

c. Memfasilitasi penyelesaian pengaduan konsumen yang dirugikan oleh pelaku di lembaga jasa keuangan sesuai dengan peraturan perundangundangan di sektor jasa keuangan.

Berdasarkan pasal tersebut, telah dijelaskan investor yang merasa dirugikan akibat adanya peristiwa kepailitan dapat melakukan aduan kepada OJK. OJK yang menerima laporan itu kemudian akan melakukan penelitian terhadap emiten. Penelitian ini dilakukan dalam upaya membuktikan bahwa memang dalam hal kepailitan terdapat kecurangan yang dilakukan oleh emiten seperti penipuan saat proses keterbukaan.

Apabila pada peneilitian yang dilakukan OJK terbukti adanya kerugian investor yang disebabkan oleh tindakan emiten, maka OJK dapat melakukan gugatan keperdataan atas nama investor sesuai Pasal 30 UU OJK:

“(1) Untuk perlindungan konsumen dan masyarakat, OJK berwenang melakukan pembelaan hukum, yang meliputi: 
a. Memerintahkan atau melakukan tindakan tertentu kepada lembaga jasa keuangan untuk menyelesaikan pengaduan konsumen yang dirugikan oleh lembaga jasa keuangan dimaksud;

b. Mengajukan gugatan:

1. Untuk memperoleh kembali harta kekayaan milik pihak yang dirugikan dari pihak yang menyebabkan kerugian, baik yang berada di bawah penguasaan pihak yang menyebabkan kerugian dimaksud maupun di bawah pengusaan pihak lain dengan itikad baik; dan/atau

2. Untuk memperoleh ganti kerugian dari pihak yang menyebabkan kerugian pada konsumen dan/atau lembaga jasa keuangan sebagai akibat dari pelanggaran jasa keuangan atas peraturan perudangundangan di sektor jasa keuangan.

(2) Ganti kerugian sebagaimana dimaksud ayat (1) hurub b angka 2 hanya digunakan untuk pembayaran ganti rugi kerugian kepada pihak yang dirugikan.

Berbicara kemungkinan, maka banyak sekali kemungkinan tindakan dan kecurangan yang dapat merugikan investor. Salah satunya adalah penipuan yang dilakukan untuk menggelapkan tuntutan hukum kepailitan pada saat proses keterbukaan oleh emiten. Apabila ditemukan hal demikian, maka berdasarkan peraturan UU OJK di atas yang juga diamatkan dalam Pasal 111 UUPM sebagai berikut:

Setiap pihak yang menderita kerugian sebagai akibat dari pelanggaran atas undang-undang ini dan atau peraturan pelaksanaannya dapat menuntut ganti rugi, baik sendiri-sendiri maupun bersama-sama dengan pihak lain yang memiliki tuntutan yang serupa, terhadap pihak atau pihak-pihak yang bertanggung jawab atas pelanggaran tersebut.

Pasal-pasal tersebut di atas memberikan kemungkinan kepada investor yang merasa dirugikan akibat adanya perbuatan hukum emiten yang berujung pada pernyataan kepailitan kepada perusahaan emiten untuk melakukan upaya hukum. Adapun gugatan ini dilakukan dengan upaya mengembalikan aset yang dimiliki oleh investor baik dengan himbauan kewajiban buy back kepada emiten ataupun melakukan ganti kerugian sesuai gugatan keperdataan yang disampaikan oleh investor melalui pengadilan.

\section{Perlindungan Hukum Investor Berdasarkan Hukum Kepailitan Indonesia}

Berkaitan dengan penelitian ini, maka analisis hendak dilakukan dengan upaya mengedepankan hak-hak investor sebagai pemegang saham pada perusahaan terbuka dalam hal terjadinya kepailitan. Kasus yang digunakan dalam penelitian ini adalah kepailitan PT Surabaya Agung Industri Pulp dan Kertas Tbk. (PT SAIP Tbk) 
Putusan Pengadilan Niaga Nomor: 01/PKPU/2013/PN.Niaga.Sby tertanggal 5 Maret 2013 memutuskan bahwa PT SAIP Tbk. pailit karena telah memenuhi syarat kepailitan sebagai berikut:

a. Memiliki lebih dari satu kreditor:

1) Asiabase Resources, Pte. memiliki tagihan sebesar Rp4.037.211.791,36 (pemohon);

2) Interfiber Asia, Pte., Ltd. dengan jumlah tagihan Rp452.566.321,36 (pemohon);

3) Sanyi Resources Pte., Ltd. Sebesar Rp6.123.217.013,12 (pemohon);

b. Salah satu utang telah jatuh tempo.

Utang kepada Asiabase Resources, Pte., Ltd., yang telah dapat ditagih adalah sebesar Rp4.037.211.791,36, yang jatuh tempo berdasarkan perjanjian pada 25 Juli 2012.

Pada Pasal 2 ayat (1) UU KPKPU diberikan syarat kepailitan, yaitu: debitor yang mempunyai dua atau lebih kreditor dan tidak membayar lunas sedikitnya satu utang yang telah jatuh tempo dan dapat ditagih. Dengan dipenuhinya syarat tersebut suatu perusahaan dapat dimohonkan pailit ke pengadilan niaga. Pailitnya perusahaan akan ditentukan oleh putusan pengadilan. PT SAIP Tbk. berdasarkan uraian sebelumnya telah benar dinyatakan pailit oleh pengadilan berdasarkan ketentuan yang ada dalam Pasal 2 ayat (1) UU KPKPU tersebut.

Pada kasus PT SAIP Tbk., pemegang saham yang juga investor di pasar modal pada saat rapat verifikasi utang mengajukan tagihan atau mengajukan diri sebagai kreditor saat proses kepailitan. Langkah yang diambil oleh pemegang saham PT SAIP Tbk., yakni PT. ZT Holding Co. dan Asia Capital Management Ltd. menggugat PT SAIP Tbk. atas utang kepada dengan jumlah tagihan masing-masing sebesar Rp3.910.836.046.232,00 dan Rp83.518.504.624,00. Tagihan atau utang tersebut dianggap sebagai akumulasi dari saham dan dividen.

Hal serupa pernah dinyatakan oleh Jamin Ginting dalam tulisannya, bahwa pemegang saham publik (investor pasar modal) merupakan kreditor bersaing (konkuren). Kreditor konkuren bersaing adalah kreditor yang mendapat bagian terakhir terhadap harta pailit seandainya ada deviden dari saham tersebut yang belum dibayar kepada para pemegang saham publik. Menurutnya, sifat utang yang begitu luas dalam hukum kepailitan memungkinkan investor sebagai pemegang saham untuk menempati kedudukan kreditor dalam kepailitan. ${ }^{16}$

Untuk dapat membuktikan dalil tersebut maka perlu dikaji lebih lanjut mengenai kedudukan saham sebagai utang dalam proses kepailitan. Pasal 1 butir 6 UUK PKPU memberikan defenisi utang sebagai berikut:

\footnotetext{
16 Jamin Ginting, Loc. cit.
} 
Utang adalah kewajiban yang dinyatakan atau dapat dinyatakan dalam jumlah uang baik dalam mata uang Indonesia maupun mata uang asing, baik secara langsung maupun yang akan timbul di kemudian hari atau kontinjen, yang timbul karena perjanjian atau undang-undang dan yang wajib dipenuhi oleh debitor dan bila tidak dipenuhi memberi hak kepada kreditor untuk mendapat pemenuhannya dari harta kekayaan debitor.

Secara redaksional pada pasal tersebut yang dapat dinyatakan utang adalah:

a. Kewajiban;

b. Dapat dinyatakan dalam jumlah uang baik dalam mata uang Indonesia maupun mata uang asing;

c. Baik secara langsung maupun yang akan timbul di kemudian hari atau kontijensi;

d. Timbul karena perjanjian atau undang-undang;

e. Yang wajib dipenuhi oleh debitor;

f. Bila tidak dipenuhi memberi hak kepada kreditor untuk mendapat pemenuhannya dari harta kekayaan debitor.

Kemudian untuk dapat membuktikan bahwa saham investor dapat menjadi landasan utang dalam proses kepailitan, perlu dikaji ciri saham yang terdapat dalam ketentuan hukum perusahaan Indonesia, diantaranya sebagai berikut:

a. Pasal 52 Ayat (1) UU PT diakui bahwa saham memberikan hak tertentu kepada pemegangnya kepada pemegangnya;

b. Pasal 54 UU PT diakui bahwa saham dapat dinilai dalam nominal;

c. Pasal 70, 71, dan 72 UU PT diakui saham memberikan hak deviden kepada pemegangnya yang muncul secara berkala di kemudian hari; dan

d. Peraturan BEI No. II-A diakui bahwa proses transaksi pembelian saham di pasar modal yang dilakukan oleh investor adalah mengikat secara hukum.

Pasal 61 UU PT dijamin tentang pemenuhan hak pemegang saham yang harus diberikan kepadanya. Analisis di atas cukup membuktikan bahwa memang saham memberikan hak kepada pemegangnya untuk dapat dijadikan dasar pengajuan utang dalam proses kepailitan.

Pada Pasal 142 UU PT dijelaskan bahwa salah satu penyebab pembubaran sebuah perseroan adalah karena harta perseroan yang telah dinyatakan pailit berada dalam keadaan insolvensi yang kemudian pembubaran ini diikuti oleh proses likuidasi. Untuk menjamin hak kreditor-kreditor perseroan tersebut, maka UU PT memberikan kepastian dalam Pasal 150 UU PT bahwa harta hasil likuidasi dibagikan terlebih dahulu kepada para kreditor. Pada Pasal 52 UU PT memang diberikan hak kepada pemegang saham untuk mendapat bagian dari sisa kekayaan perseroan hasil likuidasi, namun pada Pasal 150 ayat (4) UU PT dinyatakan bahwa apabila harta 
hasil likuidasi telah dibagikan kepada pemegang saham namun ternyata masih ada kreditor yang belum mendapat bagiannya, maka pengadilan negeri dapat memerintahkan likuidator untuk menarik kembali sisa kekayaan hasil likuidasi yang telah dibagikan kepada pemegang saham untuk dibayarkan kepada kreditor yang belum mendapat bagian.

Melihat kembali kepada peraturan tersebut, tidak dibenarkan seorang pemegang saham didudukkan sebagai kreditor dalam proses kepailitan perusahaannya sendiri. Adapun seorang pemegang saham hanya akan menjadi kreditor pada saat proses kepailitan berujung pada proses likuidasi perseroan dan pemegang saham hanya mendapat bagian apabila semua kewajiban perseroan kepada seluruh kreditor telah tepenuhi. Berdasarkan ketentuan-ketentuan di atas, kedudukan investor sebagai kreditor dalam proses kepailitan perusahaan terbuka atau emiten tidaklah dimungkinkan oleh UU PT. Walaupun di kemudian hari terdapat suatu aturan yang menyatakan kedudukan investor sebagai kreditor dalam proses kepailitan perusahaan terbuka, hal tersebut tidak dapat dilakukan mengingat asas dalam UU PT bersifat statutaroty mandate atau memaksa yang ditegaskan dalam Pasal 154 UU PT:

1) Bagi perseroan terbuka berlaku ketentuan undang-undang ini jika tidak diatur lain dalam peraturan perundang-undangan di bidang pasar modal;

2) Peraturan perundang-undangan di bidang pasar modal yang mengecualikan ketentuan undang-undang ini tidak boleh bertentangan dengan asas hukum perseroan dalam undang-undang ini.

\section{E. Penutup}

Pada prinsipnya berbagai bentuk investasi akan memberikan manfaat maupun risiko, termasuk berinvestasi di pasar modal dalam bentuk saham memberikan manfaat bagi masyarakat berupa capital gain dan dividen, namun juga memiliki risiko berupa capital loss dan resiko likuidasi. Resiko likuidasi dapat disebabkan oleh adanya gugatan hukum berupa permohonan pernyataan kepailitan.

Adanya gugatan hukum berupa kepailitan dapat menyebabkan turunnya nilai saham dan berpotensi merugikan investor sehingga apabila terdapat permohonan pernyataan pailit pada perusahaan terbuka, maka sahamnya di bursa akan didelisting oleh BEl. Apabila perdagangan saham di pasar negosiasi masih tidak dapat dilakukan oleh investor, maka jalan terakhir untuk mendapatkan kompensasi dari dana yang hilang akibat kepailitan adalah melakukan tindakan hukum berupa gugatan perdata. Gugatan perdata investor ini dapat dilakukan berdasarkan kewenangannya selaku pemegang saham berdasarkan Pasal 61 UU PT dan ketentuan di bidang pasar modal melalui OJK. Adapun permohonan investor untuk menjadi kreditor pada proses kepailitan masih tidak dapat dilakukan karena adanya 
ketentuan Pasal 150 UU PT yang mengatur bahwa pemegang saham baru mendapat bagian setelah proses kepailitan berakhir likuidasi.

Peristiwa hukum kepailitan pada perusahaan terbuka sesungguhnya dapat dihindari oleh para investor dengan memanfaatkan keterbukaan informasi di pasar modal. Para investor di pasar modal diharapkan memiliki pengetahuan yang cukup tentang berinvestasi khususnya berinvestasi saham. Perlindungan yang saat ini telah diberikan oleh OJK terkait kepailitan perusahaan terbuka dapat dimaksimalkan oleh investor dengan mengajukan pengaduan apabila merasa dirugikan dengan terjadinya kepailitan perusahaan terbuka.

\section{Daftar Pustaka}

\section{Buku}

Gunawan Widjaja dan Wulandari Risnamanitis D, Seri Pengetahuan Pasar Modal: Go Public dan Go Private di Indonesia, Cetakan Kesatu, Kencana, Jakarta, 2009. Jusuf Anwar, Pasar Modal Sebagai Sarana Pembiayaan dan Investasi, Seri Pasar Modal 1, Alumni, Bandung, 2005.

Lastuti Abubakar, Transaksi Derivatif di Indonesia: Tinjauan Hukum tentang Perdagangan Derivatif di Bursa Efek, Books Terace \& Library, Bandung, 2009.

Pandji Anoraga, Pengantar Pasar Modal, Rineka Cipta, Jakarta, 2010.

Sawidji Widoatmodjo, Cara Cepat Memulai Investasi Saham Panduan Bagi Pemula, Elex Media Komputindo, Jakarta, 2004.

Sumantoro, Aspek Hukum Pasar Modal dalam hukum dan Pembangunan No. 1, Fakultas Hukum Universitas Indonesia, Jakarta, 1978.

Tim Penyusun, Ikhtisar Ketentuan Pasar Modal, National Legal Reform ProgramBadan Pengawas Pasar Modal dan Lembaga Keuangan, Jakarta, 2010.

\section{Dokumen Lain}

Bursa Efek Indonesia, "Panduan Go Public", http://www.idx.co.id/portals/khusus PDF/go\%20public\%20new2.pdf

Jamin Ginting, "Kedudukan Pemegang Saham (Investor) dalam Kepailitan Perusahaan Go Public", Law Review Fakultas Hukum Universitas Pelita Harapan Jakarta, Volume IV, No. 3, Maret 2005.

\section{Dokumen Hukum}

Undang-Undang Nomor 8 Tahun 1995 tentang Pasar Modal. Undang-Undang Nomor 37 Tahun 2004 tentang Kepailitan dan Penundaan Kewajiban Pembayaran Utang. 
Undang-Undang Nomor 40 Tahun 2007 tentang Perseroan Terbatas.

Undang-Undang Nomor 21 Tahun 2011 tentang Otoritas Jasa Keuangan.

Peraturan PT Bursa Efek Jakarta No. II-A tentang Pedagangan Efek.

Peraturan PT Bursa Efek Jakarta No. I-I tentang Penghapusan Pencatatan dan

Pencatatan Kembali Saham di Bursa.

Bapepam-LK No. X.K.1 tentang Keterbukaan Informasi yang Harus Segera Diumumkan Kepada Publik.

Peraturan Bapepam-LK No. X.K.6 tentang Kewajiban Penyampaian Laporan Tahunan Bagi Emiten atau Perusahaan Publik.

Peraturan Bapepam-LK No. X.K.5 tentang Keterbukaan Indormasi Bagi Emiten atau Perusahaan Publik yang Dimohonkan Pernyataan Pailit. 